\title{
Distribution of D543N NRAMP1 polymorphism in tuberculosis patients from Kupang, east region of Indonesia
}

\author{
Trevino A. Pakasi, ${ }^{1}$ Ani Melani, ${ }^{2,3}$ Aulia Bramantyo, ${ }^{1}$ Ikhwanuliman Putera, ${ }^{1}$ Ikrar Syahmar, ${ }^{1}$ Elvina Karyadi, \\ Edhyana Sahiratmadja ${ }^{2,3}$ \\ ${ }^{1}$ Department of Community Medicine, Faculty of Medicine, Universitas Indonesia, Jakarta, Indonesia \\ ${ }^{2}$ Department of Biochemistry, Faculty of Medicine, Universitas Padjadjaran, Bandung, Indonesia \\ ${ }^{3}$ Health Research Unit, Faculty of Medicine, Universitas Padjadjaran, Bandung, Indonesia \\ ${ }^{4}$ South East Asia Minister of Education Organization Tropical Medicine, Universitas Indonesia, Jakarta, Indonesia
}

\begin{abstract}
Abstrak
Latar belakang: Natural resistance associated machrophage protein (NRAMP) adalah pengangkut proton/ kation divalen yang memegang peranan dalam transportasi besi di fagosom. Variasi gen NRAMP1 telah dilaporkan berhubungan dengan kerentanan terhadap tuberkulosis karena Mycobacterium tuberculosis (MTb), agen kausatif dari tuberkulosis (TB), berkompetisi dengan inangnya untuk mendapatkan zat besi guna metabolisme MTb. Penelitian ini bertujuan untuk mendapatkan gambaran polimorfisme NRAMP pada pasien TB di Kupang, Nusa Tenggara Timur.

Metode: Desain studi ini adalah kasus kontrol, dengan kasus adalah pasien TB paru, kasus baru berusia 15-55 tahun dengan pemeriksaan bakteri tahan asam positif. Sedangkan kontrol diambil dari tetangga tanpa keluhan TB atau riwayat pengobatan TB. Data demografis dan sampel darah diambil untuk pemeriksaan polimorfisme. Metode PCR/RFLP digunakan untuk mengetahui apakah satu nukleotida polimorfisme D543N dari NRAMP1 berasosiasi dengan TB.

Hasil: Sebanyak 64 pasien dengan 51 kontrol berpartisipasi dalam penelitian ini. Terdapat perbedaan signifikan genotipe NRAMP1 antara pasien TB dan kontrol sehat $(p=0,014)$. Lebih lanjut, polimorfisme D543N memberikan hubungan signifikan hanya pada subjek laki-laki. Meskipun jumlah subjek terbatas, polimofisme D543N NRAMP1 di wilayah endemik di wilayah endemik di Kupang, memperlihatkan adanya hubungan dengan kerentanan TB. Berbeda dengan studi di Jakarta, Bandung, dan Makassar, mereka tidak menunjukkan adanya asosiasi ini. Populasi Kupang kemungkinan mempunyai kemiripan latar belakang genetik dengan populasi Afrika, di mana mikobakterium yang menginfeksi sebagian besar populasi Kupang adalah Mycobacterium africanum. Penambahan jumlah subjek akan meningkatkan kekuatan dari studi ini dan kemungkinan terpenuhinya keseimbangan Hardy-Weinberg untuk mendeteksi hubungan yang jelas antara polimorfisme ini dan kerentanan terhadap TB.
\end{abstract}

Kesimpulan: Terdapat perbedaan proporsi polimorfisme NRAMP1 yang signifikan, terutama pada pasien laki-laki, tetapi perbedaan ini belum memenuhi persamaan Hardy-Weinberg. (Med J Indones. 2012;21:160-5)

\begin{abstract}
Background: Natural resistance associated macrophage protein (NRAMP) is a proton/ divalent cation transporter which play a role in iron trafficking in the phagosomes. Variations in NRAMP1 gene have been reported to be associated with susceptibility to tuberculosis (TB) because Mycobacterium tuberculosis (MTb), the causative agent of TB, compete with its host to uptake iron for its metabolism. The study aimed to describe the polymorphism of NRAMP among TB patients in Kupang, East Nusa Tenggara.

Methods: This is a case-control study, cases were pulmonary TB, new patients, aged 15-55 years with sputum smear positive for acid fast bacili. Control were surrounding neighbours without symptoms and history of TB. All demographic information and blood sample were taken for polymorphism. PCR/RFLP method was performed to explore whether single nucleotide polymorphism D543N of NRAMP1 gene is associated with susceptibility to TB.

Results: The study involved 64 pulmonary TB patients and 51 healthy controls. We observed a significant different in the distribution of NRAMP1 genotypes frequencies between TB patients and healthy controls $(p=0.014)$. Moreover, D543N polymorphism gave significant association only in male subjects. Though the numbers of the subjects are limited, D543N NRAMP1 polymorphism in endemic region in Kupang, the eastern part of Indonesia, seems to be associated with the susceptibility to TB. This is in contrary to studies reported in other part of Indonesia: i.e from west part (Jakarta, Bandung) and central part (Makassar). The population from Kupang may similar genetic background as African population, as Mycobacterium infected in population from Kupang is mostly Mycobacterium africanum. Increasing the number of subjects may enhance the power of the study and possibility to meet Hardy-Weinberg Equilibrium to detect the true associations of this polymorphism in susceptibility to TB.
\end{abstract}

Conclusion: There was a significant difference of polymorphism NRAMP1 which more pronounced among male subjects, however this has not yet fulfilled the Hardy-Weinberg equilibrium. (Med J Indones. 2012;21:160-5)

Keywords: D543N NRAMP1 polymorphism, eastern part of Indonesia, Kupang, tuberculosis

Mycobacterium tuberculosis (MTb), causative agent of tuberculosis (TB), is an intracellular microorganism that replicates within phagosomes of host macrophages.
MTb competes with the host to acquire iron in order to survive and grow. ${ }^{1}$ Natural resistance associated macrophage protein (NRAMP) is a proton/ divalent 
cation transporter that might play a role in iron trafficking in the phagosomes. NRAMP1 is a metal transporter protein localized in late endosomal and lysosomal compartments, and probably plays an important role to transfer diferric iron across the phagosome membrane. $^{2}$

Several susceptibility-associated genetic polymorphisms have been proposed to explain differential susceptibility to $\mathrm{TB}$ such as vitamin $\mathrm{D}$ receptor (VDR), and other cytokine and cytokine receptor related genes i.e. TNF, IL-12, IFNG, IFNGR, etc. since the protection to MTb is through cellular mediated immune system. ${ }^{3}$ Special attention was drawn for the interaction between iron as a nutrient that is needed both for MTb and the host. Study that firstly described in Gambia had reported that subtle variations in the NRAMP1 gene, encoding the natural resistance associated macrophage protein i.e. INT4, D543N and the 3' UTR, may result in a higher risk for having TB. ${ }^{4}$ Since then, study about TB susceptibility tend to have association with NRAMP1 variations, also known as SLC11A1, a solute carrier family 11 members, was reported in different populations in other continents, such as in Japan, ${ }^{5}$ China, ${ }^{6}$ as well as in Caucasian in the USA, ${ }^{7}$ Denmark, ${ }^{8}$ across the African countries, ${ }^{9}$ Latin American, ${ }^{10}$ Taiwan, ${ }^{11}$ and Thailand. ${ }^{12}$

However, conflicting results occurred in other part of the world. This discrepancy might suggest that ethnicspecificity contribute to susceptibility to TB. ${ }^{13}$ From Indonesia, NRAMP1 seems not to associate with TB susceptibility in Java, western part of Indonesia, ${ }^{14}$ and Celebes, central part of Indonesia. ${ }^{15}$ Hence, metaanalysis about NRAMP1 and TB susceptibility has showed a strong association. ${ }^{16}$ Moreover, NRAMP1 gene was also associated with severity to $\mathrm{TB},{ }^{17} \mathrm{~TB}$ pleurisy. ${ }^{18}$ MDR-TB and severity to HIV. ${ }^{2}$ Further study has shown that polymorphism in NRAMP1 gene were associated with TB caused by the Beijing strain. ${ }^{19}$

As our previous study found different population of MTb between West Java and Kupang, and also ethnicspecificity might contribute to the suceptibility, we would like to explore the NRAMP1 susceptibility to TB from Kupang, Eastern part of Indonesia. Mapping the host genetic background and geographical variation in Indonesia may provide knowledge on how the MTb may infect certain population.

\section{METHODS}

\section{Patients recruitment}

In a case-control study in Kupang, sixty-four tuberculosis patients who had been diagnosed with sputum smear positive and finished all free anti-TB treatment according to national TB program were recruited. All patients, aged $>15$ years, were included for blood examination after written informed consent was obtained from all subjects. Full blood counts were performed in all subjects. This case-control study was also a part of larger TB study in East Indonesia regarding nutrition intervention on $\mathrm{TB}$ treatment. We expect that smaller city as in Kupang will have less interaction with other ethnic group, and therefore the population might have purer gene rather than big cities in West Java or Celebes. The study design was approved by Faculty of Medicine, Universitas Indonesia, Jakarta ethical committees. Patients were not tested for HIV and diabetes mellitus.

\section{Control recruitment}

The research team also randomly recruited 51 unmatched healthy control subjects from the same area where the cases lived, with similar socio-economic status. Controls were interviewed using the same standardized questionnaire and underwent the blood sampling. The controls had never been diagnosed as TB patient before and had not shown any clinical symptoms of TB. In both group, we also checked whether they had ever been vaccinated against tuberculosis based on presenting BCG scar in subject's arm. Subjects were classified as anemia or not, based on haemoglobin concentration from the blood examination, with correction for age and sex. ${ }^{20}$ We considered that people lived in rural Timor were less migrating and, therefore, less mutation and had constant allele frequencies.

\section{Genotyping of NRAMP1 single nucleotide polymorphisms}

After written consent was obtained, peripheral blood was drawn. Then, peripheral blood mononuclear cells (PBMCs) were separated and genomic DNA was isolated from the EDTA blood. D543N nucleotide $(1703 \mathrm{G} \rightarrow \mathrm{A}$ in exon 15 , causing an aspartate to asparagine substitution at codon 543) polymorphisms (SNPs) at 3' untranslated region (3'UTR) in the gene NRAMP1 were analysed and only D543N SNP was explored as this SNP was proposed to have SNP D543N of SLC11A1gene was performed using PCR/ RFLP method to explore whether this polymorphism is associated with susceptibility to TB.

\section{Statistical analysis}

Data from the questionnaires, laboratory analyses, and genotypings were analysed using PASW Statistics version 18.0. Kolmogorov-Smirnov test was performed 
to check the normality of the data. We also checked whether all subjects as well as patient group and control group met Hardy-Weinberg Equilibrium. All statistical analyses were 2 -sided and $p$ values $<0.05$ were considered as statistically significant.

\section{RESULTS}

A total number of 64 pulmonary tuberculosis patients and 51 healthy controls were recruited in this study. The median age for patients was 27.5 years (range 17-59 years) whereas in the healthy control group was 33 years (range $15-55$ years). The characteristics of all subjects are presented in Table 1. Sex, history of contact with tuberculosis patients, and BCG scar were found to have significant difference in this study. In the patients, 40 subjects $(62.5 \%)$ were male, compared to $19(37.3 \%)$ in healthy control group (p $<0.05$ ). History of contact with tuberculosis patients was more often found in the patients $(p<0.05)$. Furthermore, BCG scar were more rarely found among the patients $(\mathrm{p}<0.05)$.

Tuberculosis patients generally have association with anemia. Hemoglobin concentration was higher in healthy control group. In this study, anemia was found in 46 tuberculosis patients (71.9\%), compared to only 3 subjects in control group $(5,9 \%)(p<0.05)$ (Table 1).

\section{NRAMP1 gene polymorphisms and susceptibility to TB}

The genotypes of the NRAMP1 D543N polymorphisms were not in Hardy-Weinberg equilibrium in the total group of individuals. Yet, only the control group was in Hardy-Weinberg equilibrium. Variant allele frequencies were counted for 0.27 . Genotype frequencies of $\mathrm{G} / \mathrm{G}, \mathrm{G} / \mathrm{A}$, and $\mathrm{A} / \mathrm{A}$ at D543N locus were shown in table 2 . The variant genotype (G/A and $\mathrm{A} / \mathrm{A}$ ) frequency was $64.1 \%$ in patients group and $39.2 \%$ in controls.

The apparent association of D543N polymorphism and tuberculosis was shown in variant genotypes ( $\mathrm{p}$ $=0.014)$. We only found one homozygous pattern (AA) in this study that is categorized as control (Table 2).

\section{Association of D543N polymorphism with tuberculosis in rural Timor, stratified by sex}

The genotype distribution among subjects was analysed with stratification by sex. Significant differences in genotype distribution between patients group and controls were only apparent among male subjects. Furthermore, in this study, male subject was also account to have significant difference in tuberculosis (Table 3).

Table 1. General characteristics of the subjects

\begin{tabular}{lccc}
\hline Variables & $\begin{array}{c}\text { TB patients } \\
\mathrm{n}=64\end{array}$ & $\begin{array}{c}\text { Controls } \\
\mathrm{n}=51\end{array}$ & Total \\
\hline $\begin{array}{l}\text { Age, years (range) } \\
\text { Sex* }\end{array}$ & $27.5(17-59)$ & $33(15-55)$ & $30(15-59)$ \\
Male (\%) & $40(62.5)$ & $19(37.3)$ & $59(51.3)$ \\
Female (\%) & $24(37.5)$ & $32(62.7)$ & $56(48.7)$ \\
Contact* & & & \\
Yes (\%) & $19(29.7)$ & $2(3.9)$ & $21(18.3)$ \\
No (\%) & $23(35.9)$ & $49(96.1)$ & $72(80.9)$ \\
Do not know (\%) & $22(34.4)$ & 0 & $22(19.2)$ \\
Yes (\%) & $19(29,7)$ & $35(68,6)$ & $54(47)$ \\
No (\%) & $37(57,8)$ & $14(27,5)$ & $51(44.3)$ \\
Not sure (\%) & $8(12,5)$ & $2(3,9)$ & $10(8.7)$ \\
Hemoglobin (g/dL) & $11.2 \pm 2.1$ & $14.7 \pm 1.6$ & $12.7 \pm 2.5$ \\
Anemia*a & & & \\
Yes (\%) & $46(71.9)$ & $3(5.9)$ & $49(42.6)$ \\
No (\%) & $18(28.1)$ & $48(94.1)$ & $66(57.4)$ \\
\hline
\end{tabular}

*significant difference $(\mathrm{p}<0.05)$ of the proportion

$\alpha$ Anemia threshold: male $13.0 \mathrm{~g} / \mathrm{dL}$; female (non pregnant) $12.0 \mathrm{~g} / \mathrm{dL}$ 
Table 2. Distribution of D543N SNPs among tuberculosis patients (cases) and their controls in Timor Island

\begin{tabular}{llccccc}
\hline Polymorphism & Allele or genotype & \multicolumn{2}{c}{$\begin{array}{c}\text { Frequency } \\
\text { in cases (\%) }\end{array}$} & $\begin{array}{c}\text { Frequency } \\
\text { in controls (\%) }\end{array}$ & p \\
\hline D543N & G & 64 & $(60.9)$ & 50 & $(70.4)$ & n.a \\
$(1627 \mathrm{G}>\mathrm{A})$ & $\mathrm{A}$ & 41 & $(39.1)$ & 21 & $(29.6)$ & \\
& $\mathrm{G} / \mathrm{G}$ & 23 & $(35.9)$ & 30 & $(58.8)$ & $0.014^{*}$ \\
& G/A & 41 & $(64.1)$ & 20 & $(39.2)$ & \\
& A/A & 0 & $(0)$ & 1 & $(2.0)$ & \\
\hline
\end{tabular}

n.a $=$ not analysed

* Genotype G/A and A/A were combined in analysis (Pearson Chi-square test)

Table 3. Association between D543N polymorphism and tuberculosis in Timor Island, stratified by sex

\begin{tabular}{|c|c|c|c|c|}
\hline \multirow[b]{2}{*}{ sex, genotype } & \multicolumn{2}{|c|}{ No. (\%) of subjects } & \multirow[b]{2}{*}{$\mathrm{OR}^{*}(95 \% \mathrm{CI})$} & \multirow[b]{2}{*}{$\mathrm{p}^{\mathrm{a}}$} \\
\hline & $\begin{array}{c}\text { TB patients } \\
\mathrm{n}=64\end{array}$ & $\begin{array}{c}\text { Control group } \\
\mathrm{n}=51\end{array}$ & & \\
\hline \multicolumn{5}{|l|}{ male } \\
\hline $\mathrm{G} / \mathrm{G}$ & $13(20)$ & $12(23.5)$ & 1 (reference) & 0.026 \\
\hline $\begin{array}{l}\mathrm{G} / \mathrm{A} \text { and } \mathrm{A} / \mathrm{A} \\
\text { female }\end{array}$ & $27(42.2)$ & $7(13.7)$ & $3.56(1.13-11.16)$ & \\
\hline $\mathrm{G} / \mathrm{G}$ & $10(15.6)$ & $18(35.3)$ & 1 (reference) & 0.28 \\
\hline $\mathrm{G} / \mathrm{A}$ and $\mathrm{A} / \mathrm{A}$ & $14(21.9)$ & $14(27.5)$ & $1.8(0.62-5.25)$ & \\
\hline
\end{tabular}

" OR for variant genotypes (G/A and A/A) compared to wild-type genotype $(\mathrm{G} / \mathrm{G})$

a Pearson Chi-square test (significant if $\mathrm{p}<0.05$ )

\section{No significant association of D543N polymorphism with characteristics of subjects}

We tried to analyze whether D543N polymorphism had possible association with some of the subjects' characteristics. We selected three characteristics: anemia status, the presence of BCG scar, and any history of contact with tuberculosis patients. No significant associations were observed between NRAMP1 polymorphism and those characteristics (Table 4).

\section{DISCUSSION}

NRAMP1 is a protein in late endosomal compartment in machrophage which might play role as divalent cation transporter, NRAMP1 might transport iron into the phagosome. ${ }^{21,22}$ As NRAMP1 was suggested to be responsible for infection, with no exception with mycobacterial infection, it seems that NRAMP1 polymorphism is being a part of host resistance genes against Mycobacterium tuberculosis. Epidemiological studies were described that even one third of world population exposed to $\mathrm{MTb}$, only about $10 \%$ of them will develop clinical tuberculosis. ${ }^{23}$ A casecontrol study done in Gambia strengthen possible association of single nucleotide polymorphisms in NRAMP1 genes and tuberculosis infection. ${ }^{4}$ It seems that genetic susceptibility might responsible for presentation clinical tuberculosis. After that finding, many studies tried to prove further association, with different settings of population, and also with different results. ${ }^{5-13}$

In the Indonesian population, the INT4 polymorphism proved to be rare. ${ }^{15}$ In the present study we have examined the SNP of D543N to explore whether such polymorphisms are associated with susceptibility to TB. Though the numbers of the subjects were limited, D543N NRAMP1 polymorphism in endemic region in Kupang seems to be associated with the susceptibility to TB. This is in contrary to studies reported in western ${ }^{15-}$ ${ }^{24}$ and central part of Indonesia. ${ }^{16}$

Our data showed that the frequency of variant genotypes, G/A and A/A, in D543N NRAMP1 polymorphism were significantly higher in patient group, suggesting that D543N polymorphism was associated with susceptibility to tuberculosis in Kupang population. Our finding also showed that $\mathrm{G}$ allele, as wild-type allele, were still more frequently found in Kupang population. 
Table 4. Association between D543N polymorphism and characteristics of subjects

\begin{tabular}{lllllllllllll}
\hline & \multicolumn{3}{c}{ Anemia } & \multicolumn{4}{c}{ BCG Scar } & \multicolumn{4}{c}{ History of contact TB } \\
D543N polymorphism & Yes & No & p & Yes & No & Not sure & p & Yes & No & Doubt & p \\
\hline G/G & 18 & 35 & $0.083^{1}$ & 27 & 17 & 9 & $1.21^{\text {a }}$ & 3 & 43 & 7 & $1.75^{\text {b }}$ \\
G/A and A/A & 31 & 31 & & 27 & 34 & 1 & & 18 & 29 & 14 & \\
\hline
\end{tabular}

a Pearson Chi-square test (significant if $\mathrm{p}<0.05$ )

${ }^{b}$ Kolmogorov-smirnov test (significant if $\mathrm{p}<0.05$ )

The prevalence of tuberculosis was also varied by sex, history of contact with tuberculosis patients, and presenting BCG scar. Male subjects were account higher in patient group. Therefore, we analyzed the association of $\mathrm{D} 543 \mathrm{~N}$ polymorphism with tuberculosis susceptibility as stratified by sex. The result suggested a significant association between D543N polymorphism and tuberculosis susceptibility in male subjects. This finding might be different from other study in NRAMP1 polymorphism in children subjects, where female subjects were account for significant differences. ${ }^{25}$ Based on presenting BCG scar in subjects, we might suggest that subjects with no presenting BCG scar were still more susceptible for tuberculosis. This result might support the meta-analysis that $\mathrm{BCG}$ vaccination gives an average fifty percent protection against pulmonary tuberculosis, with greatest impact in tuberculosis death, meningitis and disseminated tuberculosis. ${ }^{26}$ Moreover, another factor that influences the susceptibility to infection is history of contact with tuberculosis patients. Although East Indonesia might account higher in tuberculosis prevalence, we cannot assume that all subjects lived in endemic area have same exposure to MTb, further to infection.

We also found that no significant differences were observed between D543N polymorphism and characteristics of subjects: anemia, history of contact with tuberculosis patients, and presenting BCG scar. The significant difference in anemia only observed in subjects based on tuberculosis and control grouping, not in D543N polymorphism. Anemia was observed significantly in patient group. Thus, anemia would result from chronic infection rather than having association with D543N polymorphism, similar result from previous study in Indonesian population. ${ }^{27}$ In addition, presenting BCG scar and history of contact with tuberculosis patients were suggested to have association with tuberculosis, not to polymorphisms.

The population from Kupang may harbour different genetic background compared to population in western and central part of Indonesia. Indonesian archipelago that stretches from west to east between the continent Asia and Australia harbours many ethnicities. Eastern part of Indonesia is unique, with different ethnicity that belong to Austronesian population. ${ }^{28}$ Thus, host susceptibility based on NRAMP1 polymorphism in
Kupang population might be not only different from western and central part of Indonesia, but also from other Asian and American population, also from Teheran $^{29}$ and Mexico. ${ }^{11}$ Interestingly, study on MTb genotype distribution that infects Kupang population has different structured compared to MTb that infect the Western part of Indonesia, where Beijing genotype are predominant.$^{30}$ In the Timor Island, 33\% is infected by Mycobacterium strain of Family F (East AfricanIndian) and $20 \%$ by family D (Latin American and Mediterranean), while the Beijing genotype family infect only in about $15 \%$.

One of the limitations in this study is that we did not consider other possibilities of lung diseases. Staging of MTb infection was not performed, as individuals might acquire latent MTb infection (LTBI) in which the infection of MTb does not followed by any clinical symptoms. Despite its limitation, this study, as the contrary of the previous studies in Indonesia, showed possible association of the polymorphism among close population, which might have less mix-mariage of many ethnicity in Indonesia and therefore contribute to the controlling of the infection among those who expressed polymorphism. More study on genetic susceptibility to TB are needed and therefore give contribution to the disease control within specific areas.

Further studies for more subtle variations in genes responsible in susceptibility to TB still needed. Furthermore, increasing the number of subjects may enhance the power of the study, and also increase the chance to meet HardyWeinberg equilibrium, to detect the true associations of this polymorphism in susceptibility to TB.

\section{Acknowledgment}

We are grateful to Ms. Nurul for her support in the lab work and all health personnel at the Puskesmas in Kupang, Timur Tengah Utara, Timur Tengah Selatan, and Rote Island. Thank you also to medical students of Universitas Indonesia who helped the data collection and interviewing the subjects. This study is part of the Food Integrated to Hinder Tuberculosis (FIGHT-TB) project, partly supported by the Canadian International Development Aids, through the World Vision International Indonesia. 


\section{REFERENCES}

1. Schaible UE, Kaufmann SH. Iron and microbial infection. Nat Rev Microbiol. 2004;2(12):946-53.

2. McDermid JM, Prentice AM. Iron and infection: effects of host iron status and the iron-regulatory genes haptoglobin and NRAMP1 (SLC11A1) on host-pathogen interactions in tuberculosis and HIV. Clin Sci (Lond). 2006;110(5):503-24.

3. Merza M, Farnia P, Anoosheh S, Varahram M, Kazampour M, Pajand O, et al. The NRAMPI, VDR and TNF-alpha gene polymorphisms in Iranian tuberculosis patients: the study on host susceptibility. Braz J Infect Dis. 2009;13(4):252-6.

4. Bellamy R, Ruwende C, Corrah T, McAdam KP, Whittle $\mathrm{HC}$, Hill AV. Variations in the NRAMP1 gene and susceptibility to tuberculosis in West Africans. N Engl J Med. 1998;338(10):640-4.

5. Gao PS, Fujishima S, Mao XQ, Remus N, Kanda $\mathrm{M}$, Enomoto T, et al. Genetic variants of NRAMP1 and active tuberculosis in Japanese populations. International Tuberculosis Genetics Team. Clin Genet. 2000;58(1):74-6.

6. Liu W, Cao WC, Zhang CY, Tian L, Wu XM, Habbema JD, et al. VDR and NRAMP1 gene polymorphisms in susceptibility to pulmonary tuberculosis among the Chinese Han population: a case-control study. Int J Tuberc Lung Dis. 2004;8(4):428-34.

7. Ma X, Dou S, Wright JA, Reich RA, Teeter LD, El Sahly HM, et al. 5' dinucleotide repeat polymorphism of NRAMP1 and susceptibility to tuberculosis among Caucasian patients in Houston, Texas. Int $\mathrm{J}$ Tuberc Lung Dis. 2002;6(9):818-23.

8. Søborg C, Andersen AB, Madsen HO, Kok-Jensen A, Skinhøj P, Garred P. Natural resistance-associated macrophage protein 1 polymorphisms are associated with microscopypositive tuberculosis. J Infect Dis. 2002;186(4):517-21.

9. El Baghdadi J, Remus N, Benslimane A, El Annaz $\mathrm{H}$, Chentoufi M, Abel L, et al. Variants of the human NRAMP1 gene and susceptibility to tuberculosis in Morocco. Int J Tuberc Lung Dis. 2003;7(6):599-602.

10. Niño-Moreno P, Portales-Pérez D, Hernández-Castro B, Portales-Cervantes L, Flores-Meraz V, Baranda L, et al. P2X7 and NRAMP1/SLC11 A1 gene polymorphisms in Mexican mestizo patients with pulmonary tuberculosis. Clin Exp Immunol. 2007;148(3):469-77.

11. Hsu YH, Chen CW, Sun HS, Jou R, Lee JJ, Su IJ. Association of NRAMP1 gene polymorphism with susceptibility to tuberculosis in Taiwanese aboriginals. J Formos Med Assoc. 2006;105(5):363-9

12. VejbaesyaS,ChierakulN,LuangtrakoolP,Sermduangprateep C. NRAMP1 and TNF-alpha polymorphisms and susceptibility in Thais. Respirology. 2007;12(2): 202-6

13. Delgado JC, Baena A, Thim S, Goldfeld AE. Ethnic-specific genetic associations with pulmonary tuberculosis. J Infect Dis. 2002;186(10):1463-8.

14. Sahiratmadja E, Wieringa FT, van Crevel R, de Visser AW, Adnan I, Alisjahbana B, et al. Iron deficiency and NRAMP1 polymorphisms (INT4, D543N and 3'UTR) do not contribute to severity of anaemia in tuberculosis in the Indonesian population. Br J Nutr. 2007;98(4):684-90.

15. Hatta M, Ratnawati, Tanaka M, Ito J, Shirakawa $T$, Kawabata M. NRAMP1/SLC11A1 gene polymorphisms and host susceptibility to Mycobacterium tuberculosis and
M. leprae in South Sulawesi, Indonesia. Southeast Asian J Trop Med Public Health. 2010;41(2):386-94.

16. Li HT, Zhang TT, Zhou YQ, Huang QH, Huang J. SLC11A1 (formerly NRAMP1) gene polymorphisms and tuberculosis susceptibility: a meta-analysis. Int $\mathrm{J}$ Tuberc Lung Dis. 2006;10(1):3-12.

17. Zhang W, Shao L, Weng X, Hu Z, Jin A, Chen S, et al. Variants of the natural resistance associated macrophage protein 1 gene (NRAMP1) are associated with severe forms of pulmonary tuberculosis. Clin Infect Dis. 2005;40(9):1232-6.

18. Kim JH, Lee SY, Lee SH, Sin C, Shim JJ, In KH, et al. NRAMP1 genetic polymorphisms as a risk factor of tuberculous pleurisy. Int J Tuberc Lung Dis. 2003;7(4):370-5.

19. van Crevel R, Parwati I, Sahiratmadja E, Marzuki $\mathrm{S}$, Ottenhoff $\mathrm{TH}$, Netea MG, et al. Infection with Mycobacterium tuberculosis Beijing genotype strains is associated with polymorphisms in SLC11A1/NRAMP1 in Indonesian patients with tuberculosis. J Infect Dis. 2009;200(11):1671-4.

20. World Health Organization. Worldwide prevalence of anaemia 1993-2005. Geneva: World Health Organization; 2008. ISBN 978-92-4-159665-7.

21. Gruenheid S, Gros P. Genetic susceptibility to intracellular infection: NRAMP1, macrophage function, and divalent cations transport. Curr Opin Microbiol. 2000;3(1):43-8.

22. Kuhn DE, Baker BD, Lafuse WP, Zwilling BS. Differential iron transport into phagosomes isolated from the RAW264.7 macrophage cell lines transfected with Nramp1Gly169 or Nramp1 Asp169. J Leukoc Biol. 1999;66(1):113-9.

23. Bloom BR, Small PM. The evolving relation between humans and Mycobacterium tuberculosis. N Engl J Med. 1998;338(10):677-8.

24. Nugraha J, Anggraini R. NRAMP1 polymorphism and susceptibility to lung tuberculosis in Surabaya, Indonesia. Southeast Asian J Trop Med Public Health. 2011;42(2):338-41.

25. Jin J, Sun L, Jiao W, Zhao S, Li H, Guan X, et al. SLC11A1 (formerly NRAMP1) gene polymorphisms associated with pediatric tuberculosis in China. Clin Infect Dis. 2009;48(6):733-8

26. Colditz GA, Brewer TF, Berkey CS, Wilson ME, Burdick E, Fineberg HV, et al. Efficacy of BCG vaccine in the prevention of tuberculosis: meta-analysis of the published literature. JAMA. 1994;271(9):698-702.

27. Sahiratmadja E, Wieringa FT, van Crevel R, de Visser AW, Adnan I, Alisjahbana B, et al. Iron deficiency and NRAMP1 polymorphisms (INT4, D543N, and 3'UTR) do not contribute to severity of anemia in tuberculosis in Indonesian population. Br J Nutr. 2007;98(4):684-90.

28. Karafet TM, Hallmark B, Cox MP, Sudoyo H, Downey $\mathrm{S}$, Lansing JS, et al. Major east-west division underlies Y chromosome stratification across Indonesia. Mol Biol Evol. 2010;27(8):1833-44.

29. Farnia P, Pajand O, Anoosheh S, et al. Comparison of Nramp1 gene polymorphism among TB health care workers and recently infected cases; assessment of host susceptibility. Tanaffos. 2008;7(1):19-24.

30. Parwati I, van Crevel R, Sudiro M, Alisjahbana B, Pakasi T, Kremer K, et al. Mycobacterium tuberculosis population structures differ significantly on two Indonesian Islands. J Clin Microbiol. 2008;46(11):3639-45. 